\title{
Surface Water Quality: Occurrence and Determination of Bisphenol A in Sungai Langat
}

\author{
J.Karim, M.A.M.Idrus, N.H.F.Hashim,, M.Abdullah,, S.S.Sharifuddin, M.F.Muhazeli, M.A.M.Yusof, \\ R.T.Gunggang M.F.Abdullah, H.Jamaluddin, and N.S.Abdullah \\ Water Quality Laboratory, National Research Institute of Malaysia (NAHRIM), \\ Lot 5377, Jalan Putra Permai, 43300 Seri Kembangan, Selangor, Malaysia.
}

\begin{abstract}
Rivers as surface water in Malaysia are recipients of effluents and wastewater and yet it is important water source for daily uses of some villagers living along the river. Endocrine disruptors such as Bisphenol A (BPA) can be found in river due to continuous discharge into it. The objectives of this research is to find out the occurrence and concentration of BPA in Sungai Langat and also to see how water quality parameters such as temperature, $\mathrm{pH}$, dissolved oxygen (DO), turbidity, Total Suspended Solid (TSS), Biochemical Oxygen Demand (BOD), Chemical Oxygen Demand (COD) and ammonia nitrogen (AN) affecting the concentration of BPA. 12 stations in total including upstream to downstream of Sungai Langat and also tributary of Sungai Langat. The instrument used to find out concentration of BPA is Triple Quadrupole LC/MS. The source of BPA are mainly industrial effluents and also direct domestic discharges. The water quality parameters that will affect concentration of BPA are Ammonia Nitrogen (AN), turbidity, Biochemical Oxygen Demand (BOD), Total Suspended Solid (TSS), and Chemical Oxygen Demand (COD), Dissolved Oxygen (DO). While $\mathrm{pH}$ and water temperature are also factors that will affect concentration of BPA but the significance is not shown in the analysis. It can be concluded that upstream of Sungai Langat has lower concentration of BPA than downstream.

Key words: Endocrine disruptors, Surface water, Bisphenol A, water quality parameter,
\end{abstract}

\section{INTRODUCTION}

Emerging evidence from wildlife and laboratory studies indicates that some chemicals may interfere with the endocrine system. Compounds identified as endocrine-disrupting chemicals (EDCs) include pesticides, polychlorinated biphenyls (PCBs), dioxins, furans, alkyl phenols, and steroid hormones (natural and synthetic). The steroid hormones are of special concern due to their potency. The natural sex hormone estradiol and its metabolites (estrone and estriol) and the synthetic steroid ethinylestradiol are excreted in the urine of mammals and can be found in surface and ground waters. Other EDCs, such as the alkylphenols-nonylphenol, bisphenol $\mathrm{A}$ and pentachlorophenol are derived from industrial and domestic activities and also occur in environmental waters [1-7]. Bisphenol A (BPA) is a chemical that has been attracting increased attention because of its high potential for human exposure. Bisphenol A (BPA) is used as the base compound in the manufacture of plastics [1]. It is also used in multitude of products including food and beverage packaging, flame retardants, adhesives, building materials, electronic components, and paper coatings [8]. Worldwide, over 6 billion pounds of BPA are produced each year and over 100 tons are released into the air annually [1]. BPA has been shown to leach from food and beverage containers (via hydrolysis of polycarbonate plastics and epoxy resins) [9], dental sealants and composites [10] under normal conditions of use [5], these have been the major sources of human exposure. While the source for human exposure to BPA is food and liquid storage containers, BPA is released into the environment through either sewage treatment effluent (via human-ingested BPA being eliminated through sewage; [11]), landfill leachates (via hydrolysis of BPA from plastics; [12]), or natural degradation of 
polycarbonate plastics. While sewage effluent and landfill leachates are point sources of BPA in the environment, fragments of epoxy resins and polycarbonate plastic debris entering the watershed through runoff are non-point sources. The Sungai Langat Basin is one of the most populated river basins in Malaysia. As a result, it is surrounded by various environmental stresses of which agricultural activity is a dominant cause. For this study, concentration measurement and correlation of Bisphenol A and water quality index parameter were determined.

\section{EXPERIMENT}

\section{Water Samplling}

The Sungai Langat Basin occupies three distinct areas of the Putrajaya Federal Territory, the southern part of Selangor State and the northern part of Negeri Sembilan State. The basin catchment area is approximately 1815 square kilometres $(\mathrm{km} 2)$ and lies between latitudes $2^{\circ} 40^{\prime} 152^{\prime}{ }^{\prime} \mathrm{N}-3^{\circ} 16^{\prime} 15^{\prime}$ ' $\mathrm{N}$ and longitudes $101^{\circ} 19^{\prime} 10^{\prime \prime} \mathrm{E}-$ $102^{\circ} 1$ '10' $\mathrm{E}$. The basin contains three topographical types: a lowland area, a hilly area and a mountainous area ([13],[14]). Swamps also exist along the river. In general, the topography of the basin is flat in the west, and from hilly to mountainous in the east and the north. More than half of the catchment is categorised as 'steepland'. The basin has three major tributaries: the Sungai Langat, the Semenyih River and the Labu River. The main river in the basin, the Sungai Langat, is 141 kilometres $(\mathrm{km})$ long. It flows from the high hills in the north towards the flat west, turns westward towards the coast in the state of Selangor and ends in two estuaries: the Melacca Strait and Lumut Strait. The Melacca Strait is situated to the north of the Lumut Strait. The Sungai Langat Basin acts as a catchment area supporting approximately 1.2 million people. There are two major impoundments (the Langat Dam and Semenyih Dam) and eight water treatment plants that supply water to the entire basin.

The surface water samples from 12 locations were collected using $250 \mathrm{~mL}$ amber glass bottles and avoiding the immediate vicinity of wastewater (industrial/domestic) discharge point. Then they were immediately transported in cold condition to the laboratory and stored at $4^{\circ} \mathrm{C}$ until chemical extraction. Water quality index parameter were also measured for all 12 locations as per Figure 1.

\section{Quality Assurance and Quality Control}

All analytical procedures were monitored under quality assurance and quality control measures. Duplicate and a standard quality control were measured to assure accurate result will be presented by the instrument.

\section{Reagents and Solutions}

BPA standard 4,4'-Isopropylidenediphenol $97 \%$ was pruchased from Acros Organics. Meanwhile HPLC grade ammonium acetate, methanol, acetonitrile were purchased from Fisher Scientific. Ultra pure water (UPW) used must be $18.2 \mathrm{M} \Omega$ resistivity.

\section{Standard Preparation}

The stock solutions of BPA were prepared by dissolving $10 \mathrm{mg}$ of each chemical in $10 \mathrm{~mL}$ methanol. Working solutions for calibration and recovery check were prepared by diluting the stock solutions at required concentrations in methanol and water. All the standards were stored at $-20^{\circ} \mathrm{C}$.

\section{Sample Extraction}

All surface water were centrifuged and filter. Sample were mix with methanol in $1 \mathrm{ml}$ vial before inject to the LC MS/MS.

\section{Instrument}

Identification of peak concentrations was made by means of a chromatogram of a standard solution of each compound. BPA was identified by respective retention time and peak area. Optimum condition to indentified and quantified Bisphenol A are as per Table 1.

Table 1.Chromatographic conditions for Bisphenol A Instrument High-Performance Agilent 6470A Triple Quadrupole LC/MS

\begin{tabular}{ll}
\hline Analytical Column: & Zorbax Eclipse Plus C18 \\
& $2.1 \times 50 \mathrm{~mm}, 1.8 \mathrm{um}$ \\
Guard Column & $\begin{array}{l}: \text { Infinity In-line filter with 0.3um SS } \\
\text { frit }\end{array}$ \\
Injection volume & $: 10 \mathrm{uL}$ \\
Mobile phase & $: \mathrm{A}=\mathrm{UPW}+5 \mathrm{mM}$ ammonium acetate \\
& $\mathrm{B}=(90 \% \mathrm{CAN}+10 \% \mathrm{UPW})+5 \mathrm{mM}$ \\
& ammonium acetate \\
Run time & $: 6.4 \mathrm{~min}+1.5 \mathrm{~min}$ post time \\
Flow rate & $: 0.4 \mathrm{ml} / \mathrm{min}$
\end{tabular}




\section{Water Quality Analysis}

All 12 locations were also measured for water quality analysis such as $\mathrm{pH}$, Turbidity, Total Suspended Solids (TSS), Ammoniacal Nitrogen (AN), Biochemical Oxygen Demand (BOD), Chemical Oxygen Demand (COD), Dissolved Oxygen (DO).

\section{RESULT AND DISCUSSION}

\section{Bisphenol A in surface water}

BPA compound precursor is $227 \mathrm{~m} / \mathrm{z}$.

Meanwhile the product ion is $212 \mathrm{~m} / \mathrm{z}$ and $133 \mathrm{~m} / \mathrm{z}$ ion.
Fragmentor voltage and collision energy used are $115 \mathrm{~V}$ and $25 \mathrm{~V}$. BPA appear at the retention time around 6.5. as show in Figure 1. A calibration curve for each residue was constructed at six different concentrations of a mixed standard: 25.0, 20.0, 15.0, 10.0, 5.0, 1.0, 0.5 and $0.1 \mathrm{ppb}$. These curves show $\mathrm{r}$ value of 0.996 as Figure 2. The standard quality control gives $5.0 \mathrm{ppb}$ with $100 \%$ accuracy. Detail of the sampling points and the concentration of BPA occurred is shown in Table 2.

Table 2: BPA mean concentration according to site sampling point

\begin{tabular}{|c|c|c|c|}
\hline Station & Sampling Point & Site description & $\begin{array}{l}\text { Mean } \\
\text { concentration } \\
\text { of BPA (ppb) }\end{array}$ \\
\hline P1 & Pangsun & $\begin{array}{l}\text { Recreational area, receive water flow from } \\
\text { Sungai Langat Dam }\end{array}$ & 12.2395 \\
\hline $\mathrm{P} 2$ & Sg.Semungkis & Recreational area and waste dumping area & 14.1108 \\
\hline P3 & $\begin{array}{l}\text { Kampung Batu 13, } \\
\text { Hulu }\end{array}$ & $\begin{array}{l}\text { Residential area, crops and waste dumping } \\
\text { area }\end{array}$ & 19.6658 \\
\hline P4 & Hulu Langat & $\begin{array}{l}\text { Residential area, crops and waste dumping } \\
\text { area }\end{array}$ & 17.6361 \\
\hline P5 & $\begin{array}{ll}\text { Sg. } & \text { Semenyih } \\
\text { upstream } & \end{array}$ & $\begin{array}{l}\text { Illegal waste dumping area, receives input } \\
\text { from cattle farm and crops plantation }\end{array}$ & 20.1396 \\
\hline P6 & $\begin{array}{l}\text { Budiman Industrial } \\
\text { area }\end{array}$ & $\begin{array}{l}\text { Construction site, paper mills, metal } \\
\text { industries, illegal waste dumping area }\end{array}$ & 23.8443 \\
\hline P7 & Sungai Ramal & $\begin{array}{l}\text { Residential area and waste dumping area. } \\
\text { Receive input from sand mining, oil palm } \\
\text { plantation and construction site }\end{array}$ & 18.8837 \\
\hline P8 & Dengkil & $\begin{array}{l}\text { Residential area, waste dumping area, and } \\
\text { crops plantation }\end{array}$ & 16.6980 \\
\hline P9 & $\begin{array}{l}\text { STP effluent near Sg. } \\
\text { Batang Nilai }\end{array}$ & $\begin{array}{l}\text { Residential area, construction site, waste } \\
\text { dumping area }\end{array}$ & 20.6258 \\
\hline $\mathrm{P} 10$ & Sungai Chincang & Residential area, poultry farm & 12.3459 \\
\hline $\mathrm{P} 11$ & Sungai Labu & $\begin{array}{l}\text { Plantation area, receive plantation } \\
\text { discharge and dopmestic waste }\end{array}$ & 20.5508 \\
\hline P12 & Sungai Changgang & Residential area and waste dumping area & 16.5249 \\
\hline
\end{tabular}

The levels of BPA in the Sungai Langat were the range of $2.2395 \mathrm{ppb}$ to $23.8443 \mathrm{ppb}$ respectively.
BPA was detectable at all locations (Table 2 and Figure 3). The BPA distribution in Sungai Langat showed higher concentration in the middle stream than the 
upstream regions which may be due to the urban runoff. The highest concentration of $23.8443 \mathrm{ppb}$ was detected at Budiman Industrial area (P6). Budiman Industrial area is coastal town with industrial activities, it is expected that local sewage disposal and runoff from upstream settlements may be the prime reasons. BPA is one of the ingredients used as a low cost image developer in the production of paper may therefore contribute as well. [15]. For upstream Sungai Langat, BPA shows value of $12.2395 \mathrm{ppb}$ which may be due to many tourist attractions including waterfalls, dams and sanctuary in the upper reaches of the river, so contribution from human activities may not be ruled out. Among the phenolic compounds, BPA is the most documented chemical reported in surface waters around the world. It was reported at higher levels in the European rivers, i.e. up to $2970 \mathrm{ng} / \mathrm{L}$ in Spain, $776 \mathrm{ng} / \mathrm{L}$ in Germany and up to $683 \mathrm{ng} / \mathrm{L}$ in Portugal, and also in China (up to $1040 \mathrm{ng} / \mathrm{L}$ ), than observed in Sungai Langat in the present investigation [16-20].

\section{Water Quality Index}

Seven parameters were included to determine the quality of Sungai Langat; pH, Turbidity, Total Suspended Solids (TSS), Ammoniacal Nitrogen (NH3N), Biochemical Oxygen Demand (BOD), Chemical Oxygen Demand (COD), Dissolved Oxygen (DO). Insitu measurement of turbidity and dissolved oxygen (DO), and $\mathrm{pH}$ were obtained using YSI Model 556 Multi probe system (MPS). This instrument was calibrated and cleaned before being used for the sampling. Concentration of BOD, COD, TSS, and Ammoniacal Nitrogen were determined in the laboratory. The water samples for the parameters BOD, COD and Ammoniacal Nitrogen were stored in temporary ice box container before being transported to the laboratory for analysis. For BOD parameter, water samples were collected using dark glass bottles. Bottles were totally dipped into water with the lid on. The bottle mouth was directed downward in the water at a depth of 10-15 cm below the water surface. After all the bottles were filled with water sample and free from air bubbles, the bottle lids were closed. At the end of the five-day period, the remaining dissolved oxygen was 20 measured. The relationship between oxygen that was consumed during the five days and the volume of the sample increment were then used to calculate the BOD5. COD was analyzed in the laboratory using the reactor digestion method. The reactor was heated until the temperature reached $150{ }^{\circ} \mathrm{C}$. $2 \mathrm{ml}$ of water sample was added into the HACH COD vials using clean volumetric pipet. The second vial was added with $2 \mathrm{ml}$ of deionized water. The vials were gently inverted to several times then, were placed in the reactor and heat for two hours. After that vials were cooled for about $20 \mathrm{~min}$, the reading was obtained using HACH spectrophotometer. Total Suspension Solid (TSS) was analyzed using glass fiber filter paper Whatman with 0.45 um pore size and a diameter of $47 \mathrm{~mm}$ filtered with deionizer water to ensure that no dissolved salts and impurities present. Then, the filter paper was dried at temperature of $105^{\circ} \mathrm{C}$ in the oven for two hours and weighed. Then, filter papers were cooled in desiccators before being weighed to obtain a balanced weight with temperature. Difference weight of filter paper before and after filtration was calculated to obtain the weight of suspended solids.

Total Suspended Solids $(\mathrm{mg} / \mathrm{L})=(\mathrm{A}-\mathrm{B}) \times 1000 /$ (Sample

$$
\text { volume, } \mathrm{mL} \text { ) }
$$

Where:

A: Weight of filter paper before filtration in $\mathrm{mg}$

B: Weight of filter paper after filtration in $\mathrm{mg}$

Ammoniacal Nitrogen was measured using Nesslerization method. This analysis uses the principle of colorimetric. A total of $25 \mathrm{ml}$ of water sample was filled into the measuring cylinder. $25 \mathrm{ml}$ of deionized water blank was filled into another measuring cylinder respectively. Next, 3 drops of

mineral stabilizer and solution of polyvinyl alcohol dispersant were added to both of cylinders and shaken for mixing to get the perfect solution. Then, $1 \mathrm{ml}$ of Nessler reagent was added into each of measuring cylinder and shaken. Both of measuring cylinders were left 1 minute for the reaction to begin. Finally, each solution was poured into a round sample cell to be measured with HACH spectrophotometer. The result for all parameter are shown in Table 3. 
Table 3: Water Quality Analysis and Water Quality Index for 12 sampling point

\begin{tabular}{lcccccccc}
\hline $\begin{array}{l}\text { Statio } \\
\mathrm{n}\end{array}$ & $\begin{array}{l}\text { COD } \\
(\mathrm{ppm})\end{array}$ & $\begin{array}{l}\text { BO } \\
\mathrm{D} \\
(\mathrm{pp}\end{array}$ & $\begin{array}{l}\text { AN } \\
(\mathrm{ppm})\end{array}$ & $\begin{array}{l}\text { TSS } \\
(\mathrm{pp} \\
\mathrm{m})\end{array}$ & $\begin{array}{l}\text { DO } \\
(\%)\end{array}$ & $\mathrm{pH}$ & $\begin{array}{l}\text { Turbidi } \\
\text { ty } \\
(\mathrm{NTU})\end{array}$ & $\begin{array}{l}\text { W } \\
\text { QI }\end{array}$ \\
\hline P1 & 2.5 & 1.0 & 0.748 & 10 & 95.9 & 6.33 & 2.4 & 90 \\
P2 & 2.5 & 1.0 & 0.114 & 13 & 102 & 6.6 & 73.4 & 95 \\
P3 & 7.57 & 5.7 & 2.436 & 61 & 85.1 & 6.5 & 123.3 & 75 \\
P4 & 38.93 & 10.4 & 3.705 & 24 & 25.3 & 6.16 & 19 & 49 \\
P5 & 21.76 & 10.5 & 3.132 & 10 & 87.5 & 6.71 & 110.9 & 72 \\
P6 & 7.05 & 5.4 & 1.964 & 25 & 87.8 & 6.92 & 236.1 & 80 \\
P7 & 13.65 & 8.2 & 4.988 & 35 & 60.8 & 5.99 & 344.5 & 64 \\
P8 & 11.82 & 5.3 & 3.353 & 56 & 57.9 & 6.48 & 387.5 & 66 \\
P9 & 55.6 & 10.3 & 11.58 & 14 & 54.1 & 6.78 & 20.9 & 56 \\
P10 & 16.31 & 10.5 & 1.746 & 66 & 87.4 & 6.87 & 78.4 & 72 \\
P11 & 39.62 & 10.4 & 4.825 & 66 & 36.7 & 6.88 & 64.4 & 49 \\
P12 & 10.03 & 5.2 & 3.186 & 10 & 92.8 & 6.81 & 171.8 & 79 \\
\hline
\end{tabular}

Based on the findings, Sungai Langat was classified in class III based on the WQI classification. The water quality at Sungai Langat is highly affected by

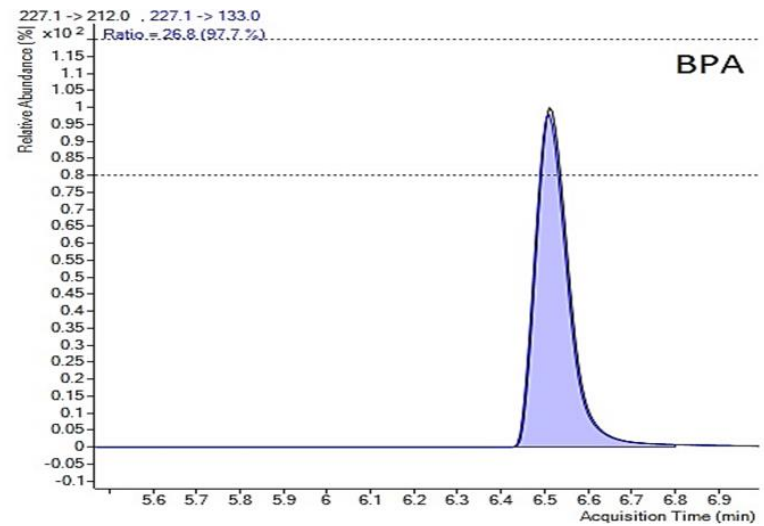

Figure 1: Relative abundance of BPA

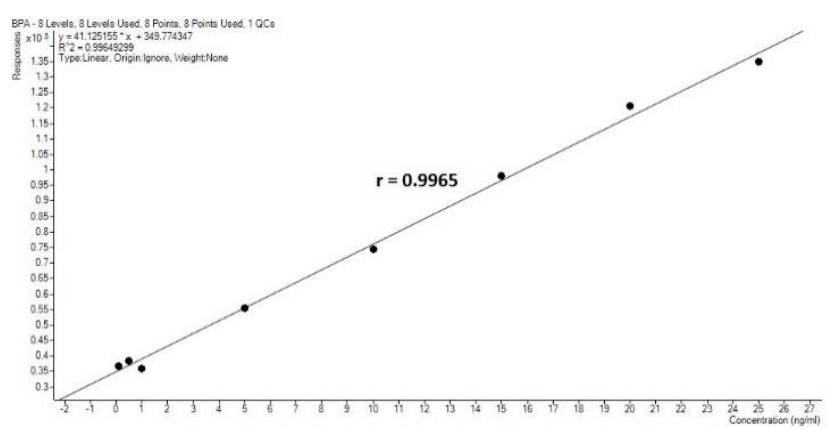

Figure 2: Calibration curve of BPA the surrounding human activities such as construction, manufacturing factories, sand mining and from domestic wastes.

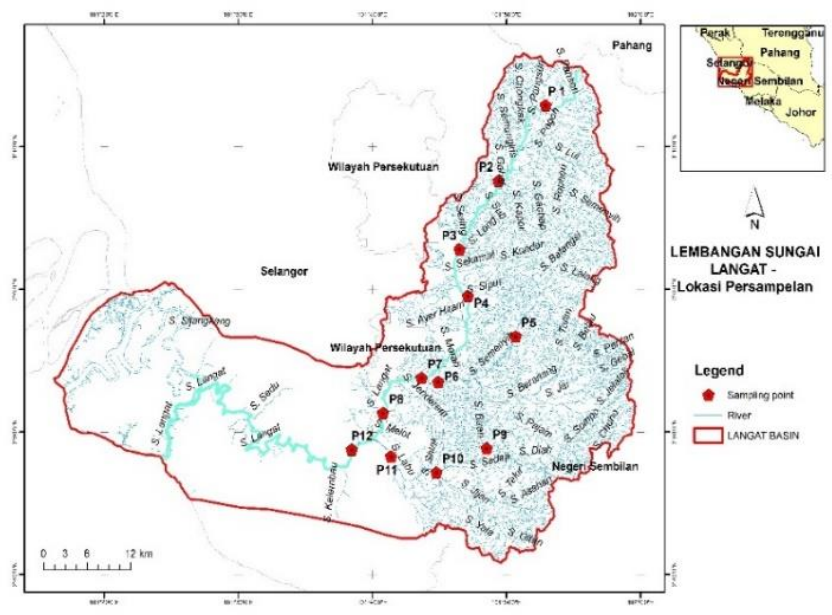

Figure 3: Map of sampling in the Sungai Langat basin

\section{CONCLUSION}

Water pollution due to various toxic solid wastes, effluents and emission are being discharged, resulting in an excessive amount of BPA in local ground water. Due to discharge of untreated industrial effluents in the sewage channels, the ground water quality is deteriorated to great extent, therefore, availability of healthy, clean and good quality drinking water is a matter of great concern especially in the urban areas. Increasing population and uncertain climatic change 
will pose heavy demands on water quality in the future. Therefore, the sources of fresh water supply especially Sungai Langat is needed to make sure it is clean for water supply and also well sustained from declining from the natural sources to be consumed by community within Langat watershed.

Therefore, it is very important to identify the pollutant sources through point source pollution based on the land use activities that took place around the Langat basin. Thus, in order to make sure the Sungai Langat is clean, the sources of pollutant discharge from the land use activities along the Sungai Langat basin must be identified and controlled.

\section{ACKNOWLEDGMENTS}

The authors acknowledge the financial support from National Hydraulic Research Institute of Malaysia (NAHRIM).

\section{REFERENCES}

[1] Vandenberg, L.N., Maffini, M.V., Sonnenschein, C., Rubin, B.S. and Soto, A.M. (2009). Bisphenol-A and the great divide: a review of controversies in the field of endocrine disruption. Endocrine Rev 30(1):75-95.

[2]US Environmental Protection Agency, (2007). Memorandum to EDSTAC Members RE:Definition of "Endocrine Disruptor". Washington D.C., USA.

[3] Renner, R., (1997). European bans on surfactant trigger transatlantic debate. Environ. Sci. Technol. 31, 316A-320A.

[4] Hayes, T.B., Collins, A., Lee, M., Mendoza, M., Noriega, N., Stuart, A.A. and Vonk, A., (2002). Hermaphroditic, demasculinized frogs after exposure to the herbicide atrazine at low ecologically relevant doses. Proc. Natl. Acad. Sci. U. S. A. 99, 5476-5480.

[5] Markey, C.M., Rubin, B.S., Soto, A.M. and Sonnenschein, C. (2003). Endocrine disruptors from Wingspread to environmental developmental biology. J Steroid Biochem Mol Biol 83:235-244.

[6] Ashkenazi, B., Mocarelli, P., Warner, M., Chee, W.Y., Gerthoux, P.M., Samuels, S., Needham, L.L. and Patterson Jr., D.G., (2003). Maternal serum dioxin levels and birth outcomes in women of Seveso, Italy. Environ. Health Perspect. 111, 947-953.

[7] Falconer, I.R., Chapman, H.F., Moore, M.R. and Ranmuthugala, G., (2006). Endocrine-disrupting compounds: a review of their challenge to sustainable and safe water supply and water reuse. Environ. Toxicol. 21, 181-191.

[8] Staples, C.A., Dorn, P.B., Klecka, G.M., O’Block, S.T., Harris, L.R., (1998). A review of the environmental fate, effects, and exposures of BisphenolA. Chemosphere 36, 2149-2173.

[9] Brotons, J.A., Olea-Serrano, M.F., Villalobos, M. and Olea, N., (1994). Xenoestrogens released from lacquer coating in food cans. Environ Health Perspect 103:608-612.

[10] Olea, N., Pulgar, R., Perez, P., Olea-Serrano, F., Rivas, A., Novillo-Fertrell, A., Pedraza, V., Soto, A.M. and Sonnenschein, C. (1996) Estrogenicity of resinbased composites and sealants used in dentistry. Environ Health Perspect 104:298-305.

[11] Meesters, R.J. and Wa, H.F.S. (2002) Simultaneous determination of 4-nonylphenol and Bisphenol $\mathrm{A}$ in sewage sludge. Anal Chem.74:3566-74.

[12] Wintgens, T., Gallenkemper, M. and Melin, T. (2003) Occurrence and removal of endocrine disrupters in landfill leachate treatment plants. Water Sci Technol. 48:127-34.

[13] Lim WY, Aris AZ, Praveena SM (2013) Application of the chemometric approach to evaluate the spatial variation of water chemistry and the identification of the sources of pollution in Langat River, Malaysia. Arab J Geosci 6(12):4891-4901. doi:10. 1007/s12517-012-0756-6

[14] Aris AZ, Lim WY, Looi LJ (2015) Natural and anthropogenic determinants of freshwater ecosystem deterioration: an environmental forensic study of the Langat River Basin, Malaysia. In: Ramkumar M, Kumaraswamy K, Mohanraj R (eds) Environmental management of River Basin ecosystems. Springer, Switzerland, pp 455-476

[15] Staples.C Dorn.P.B, Klecka.G.M, O'Block.S.T, Harris.L.R. A review of the environmental fate, effects, and exposures of bisphenol A. Chemosphere. 1998 Apr;36(10):2149-73.

[16] Alessand.C, Andre.F.M, Sabrina.S. Bisphenol A, nonylphenols, benzophenones, and benzotriazoles in soils, groundwater, surface water, sediments, and food: a review. Environ Sci Pollut Res Int. 2015; 22(8): 57115741.

[17] Cousins.I.T., Staples.C.A., Kle`cka.G.M, Mackay.D A Multimedia Assessment of the Environmental Fate of Bisphenol A. Human and Ecological Risk Assessment: Vol. 8, No. 5, pp. 11071135 (2002)

[18] Farhana.M, Wan.L.W.J. The Occurrence and Analysis of Bisphenol A (BPA) in Environmental

Samples - A Review. JOBIMB, 2015, Vol 3, No 2, 3038

[19] Huanga Y.Q., Wonga C.K.C, Zhenga J.S., Bouwmanb H, Barrac R., Wahlströmd,L B.. Nerine, Wong M.H. Bisphenol A (BPA) in China: A review of sources, environmental levels, and potential human health impacts. Environ Int (2011)

[20] Cláudia.R, Miguel.A.P, Filipe.M,Rui.M,Maria .E.T, Eduardo.R, Maria.J.R. Distribution of endocrine disruptors in the Mondego River estuary, Portugal. Environmental Monitoring and Assessment 149(1):183193. 